\title{
N-Substituted amino acids as anticorrosion additives. Part III: N-Acyl amino acids
}

\author{
J. Telegdi ${ }^{1,2}$
}

${ }^{1}$ Óbuda University, Faculty of Light Industry and Environmental Engineering, Doberdó u. 6., 1034 Budapest, Hungary

${ }^{2}$ Department of Interfaces and Surface Modification, Institute of Materials and Environmental Chemistry, Research Centre for Natural Sciences, Hungarian Academy of Sciences, Magyar tudósok körútja 2, 1117 Budapest, Hungary E-mail: telegdi.judit@,ttk.mta.hu

\begin{abstract}
$\mathrm{N}$-Acylated natural amino acids under neutral conditions were in the focus of corrosion experiments. The influence of the $\alpha$-side chain in the amino acids as well as the alkyl/aryl part of the acyl moiety on the anticorrosion activity was determined by gravimetric test and visualized by atomic force microscopy. The $\mathrm{pH}$-dependence of the inhibitive character allowed the evaluation of the acidic and alkaline conditions on the corrosion inhibition. The analysis of the efficiencies gave information about the importance of the hydrophobic chains either in the amino acid or in the acyl part and of the other functional groups (carboxyl, chloro substituent). On the basis of these numerous efficacy data one can predict in advance the anticorrosion activity of other acylated amino acids.
\end{abstract}

Key words: $N$-acylated amino acids, anticorrosion activity, $p H$-dependence, importance of the hydrophobic side chains, influence of other functional groups.

Received: July 9, 2016. Published: August 2, 2016.

doi: $\underline{10.17675 / 2305-6894-2016-5-3-6}$

\section{Introduction}

The control of corrosion in aquatic environment is important in order to avoid the deterioration of metals. The iron, which is the main component of structural materials (cooling towers, bridges, reinforced concrete, etc.) suffers undesired chemical, physical (especially mechanical) alterations caused by corrosive environment. There are several possibilities which help in mitigation of these processes. On atmospheric environment coatings can diminish the corrosion. Under fluids either coatings or additives - i.e. inhibitors - help to decrease and control the reactions which lead to metal dissolution (on the anodic side) and - depending on the $\mathrm{pH}$ of the environments - to $\mathrm{OH}^{-}$or $\mathrm{H}_{2}$ production on the cathodic side. To illustrate these processes on the iron surface in aqueous solution the following equations symbolize the reactions; the first step is the adsorption of water molecules on the metal surface, then these adsorbed molecules transform: 


$$
\begin{gathered}
\mathrm{Fe}+\mathrm{H}_{2} \mathrm{O} \Leftrightarrow \mathrm{Fe}(\mathrm{OH})_{\mathrm{ads}}+\mathrm{H}^{+}+\mathrm{e}^{-} \\
\mathrm{Fe}(\mathrm{OH})_{\mathrm{ads}} \Leftrightarrow[\mathrm{Fe}(\mathrm{OH})]^{+}+\mathrm{e}^{-}
\end{gathered}
$$

The other possibility is the so-called catalyzed mechanisms:

$$
\begin{gathered}
\mathrm{Fe}+(\mathrm{FeOH})_{\mathrm{ads}} \Leftrightarrow \mathrm{Fe}(\mathrm{FeOH}) \\
\mathrm{Fe}(\mathrm{FeOH})+\mathrm{OH}^{-} \Leftrightarrow[\mathrm{Fe}(\mathrm{OH})]^{+}+\mathrm{Fe}(\mathrm{OH})_{\mathrm{ads}}+2 \mathrm{e}^{-}
\end{gathered}
$$

In this case the last reaction determines the metal dissolution rate. The final step in both mechanisms is the conversion of $[\mathrm{FeOH}]^{+}$:

$$
[\mathrm{Fe}(\mathrm{OH})]^{+}+\mathrm{H}^{+} \Leftrightarrow \mathrm{Fe}^{2+}+\mathrm{H}_{2} \mathrm{O}
$$

The reaction on the cathode under neutral, aquatic condition is the follow:

$$
\mathrm{O}_{2}+2 \mathrm{H}_{2} \mathrm{O}+4 \mathrm{e}^{-} \Leftrightarrow 4 \mathrm{OH}^{-}
$$

But in acidic condition hydrogen evaluates on the cathode. For identification of the separate steps and the products several techniques are used (photoelectron spectroscopy, Auger-spectroscopy, Mössbauer and Raman spectroscopy, scanning electronmicroscopy, electron diffraction etc.).

The variety of molecules appropriate for corrosion inhibition is very wide. Their application depends on the metal, on the aqueous or solvent environment (ions, $\mathrm{pH}$ ). Under acidic conditions amino acids are often used as effective inhibitors [1-6]. These molecules contain not only carboxylic groups but, additionally, free amino groups, too, that under acidic conditions are protonated. But not only the nitrogen containing amino groups are responsible for the inhibitive characteristics but in some cases the other functional groups (e.g. - $\mathrm{SH})$ play important role in the inhibition. The advantage to apply amino acids for corrosion inhibition is that they are environmentally friendly, they do not cause undesired load on the nature. Under neutral conditions the free amino acids are not effective, but their substituted derivatives could be used as inhibitors.

In our previous papers three types of $\mathrm{N}$-substituted amino acids (N-hydroxymethyl, $\mathrm{N}$-carboxy methyl and $\mathrm{N}$-phosphonomethyl derivatives) were described as multifunctional inhibitors. It was demonstrated that they can inhibit not only the corrosion but the scaling, and, for some extent the microbially influenced corrosion, too [7, 8]. In this paper the anticorrosion effect of acylated natural amino acids is discussed. The influence of the $\mathrm{pH}$, the effect of the side chain of the $\alpha$-amino acids (alkyl, aralkyl, aryl, alkyl chain without and with functional group), as well as of the alkyl/aryl substituent in the acyl part will be discussed.

\section{Experimental}

\subsection{Materials}

Inhibitors: Acyl aminoacids were used as anticorrosion additives. The acylation of the amino acids were carried out by Schotten-Bauman reaction [9]. The preparation is not part 
of this paper. The amino acids are the follows: glycine, alanine ( $\alpha$ and $\beta$ ), leucine, valine, norvaline, phenylalanine, aspartic acid, glutamic acid, lysine. The acyl moieties are as follows: acetyl, caproyl, capryl, phenyl, cinnamoyl.

Metal under investigation was carbon steel (composition: Fe $99.57 \%$, C 0.05\%, Si 0.05\%, Mn $0.3 \%$, S $0.01 \%$, P $0.02 \%$ ).

\subsection{Corrosion test}

The corrosion rates were determined by gravimetric method. The efficiency ( $\eta \%)$ was calculated according to the equation:

$$
\eta=\frac{m_{0}-m_{i}}{m_{0}} \times 100[\%]
$$

where $m_{0}$ represents the weight loss of the metal coupon when inhibitor is absent, $m_{i}$ is the weight loss of the coupon measured in the presence of inhibitor.

The corrosion tests were carried out in model solution $\left(\left[0.47 \mathrm{~g} \mathrm{CaSO}_{4} \times 2 \mathrm{H}_{2} \mathrm{O}+0.23 \mathrm{~g}\right.\right.$ $\left.\mathrm{MgSO}_{4} \times \mathrm{H}_{2} \mathrm{O}+0.11 \mathrm{~g} \mathrm{NaHCO}_{3}+0.13 \mathrm{~g} \mathrm{CaCl}_{2} \times \mathrm{H}_{2} \mathrm{O}\right] / 1 \mathrm{~L}$ distilled water; the $\mathrm{pH}$ values were: $5.5 ; 7.0$ and 8.5 ).

\subsection{Surface visualization by atomic force microscopy}

The metal surface before visualization was ground with emery paper up to 1200 grit and polished with diamond past. The mirror-like surface was cleaned first with water then with acetone and dried by nitrogen. The metal samples were imaged in contact mode, on air, before and after the corrosive attack, by atomic force microscope (Digital Instruments, NanoScope III). The corrosive solution was the same as used in gravimetric measurements.

\section{Results and discussion}

The influence of the electrophile and nucleophile substituents in the hydrophobic side chain of the natural amino acids were in the focus of our research.

\subsection{Acylated glycine derivatives}

The results of the corrosion tests measured in the presence of glycine derivatives are summarized in Table 1.

Table 1. The pH-dependent corrosion inhibition efficacy of N-acyl glycines; [I]: 100ppm.

\begin{tabular}{rccc}
\hline \multirow{2}{*}{ Molecules under investigation } & \multicolumn{3}{c}{ Corrosion efficiency $\boldsymbol{\eta}(\%)$} \\
\cline { 2 - 4 } $\mathbf{H}-\mathrm{NH}-\mathrm{CH}_{2} \mathrm{COOH}$ & $\mathbf{p H}=\mathbf{5 . 5}$ & $\mathbf{p H}=\mathbf{7 . 0}$ & $\mathbf{p H}=\mathbf{8 . 5}$ \\
$\mathbf{C H}_{\mathbf{3}}-\mathbf{C O}-\mathrm{NH}-\mathrm{CH}_{2} \mathrm{COOH}$ & 7.8 & 49.8 & -5.7 \\
$\mathbf{C H}_{\mathbf{3}}-\left(\mathbf{C H}_{\mathbf{2}}\right)_{4}-\mathbf{C O}-\mathrm{NH}-\mathrm{CH}_{2} \mathrm{COOH}$ & 1.8 & 13.1 & 8.5 \\
\hline
\end{tabular}




\begin{tabular}{rccc}
\hline \multirow{2}{*}{ Molecules under investigation } & \multicolumn{3}{c}{ Corrosion efficiency $\boldsymbol{\eta}(\%)$} \\
\cline { 2 - 4 } $\left.\mathbf{C H}_{\mathbf{3}}-\mathbf{C} \mathbf{C H}_{\mathbf{2}}\right)_{\mathbf{8}}-\mathbf{C O}-\mathrm{NH}-\mathrm{CH}_{2} \mathrm{COOH}$ & $\mathbf{p H}=\mathbf{5 . 5}$ & $\mathbf{p H}=\mathbf{7 . 0}$ & $\mathbf{p H}=\mathbf{8 . 5}$ \\
\hline $\mathbf{C}_{\mathbf{6}} \mathbf{H}_{\mathbf{5}}-\mathbf{C H}=\mathbf{C H}-\mathbf{C O}-\mathrm{NH}-\mathrm{CH}_{2} \mathrm{COOH}$ & - & 29.2 & 6.3 \\
$\mathbf{C}_{\mathbf{6}} \mathbf{H}_{5}-\mathbf{C O}-\mathrm{NH}-\mathrm{CH}_{2} \mathrm{COOH}$ & - & 19.1 & - \\
$\mathbf{H}_{\mathbf{2}} \mathbf{N}-\mathbf{C H}_{\mathbf{2}}-\mathbf{C O}-\mathrm{NH}-\mathrm{CH}_{2} \mathrm{COOH}$ & - & 8.23 & - \\
\hline
\end{tabular}

The acylation of glycine does not improve the anticorrosion efficacy of the basic amino acid molecule. There is a significant decrease in efficiency both in acidic and alkaline environment. The acylated glycine molecules do not act as corrosion inhibitors.

\subsection{The influence of hydrophobic side chains in the amino acids}

\subsubsection{Acyl derivatives of $\alpha$-alanine, $\beta$-alanine, leucine and $\alpha$-amino butyric acid}

Table 2. $\mathrm{pH}$-dependent anticorrosion efficacy of acyl derivatives of $\alpha$ - alanine, $\beta$-alanine and leucine ([I]: $100 \mathrm{ppm})$.

\begin{tabular}{|c|c|c|c|}
\hline \multirow{2}{*}{ Molecules under investigation } & \multicolumn{3}{|c|}{ Corrosion efficiency $\eta(\%)$} \\
\hline & $\mathrm{pH}=5.5$ & $\mathbf{p H}=\mathbf{7 . 0}$ & $\mathrm{pH}=8.5$ \\
\hline $\mathrm{H}_{2} \mathrm{~N}-\mathrm{CH}_{2}-\mathrm{COOH}$ & - & 49.8 & - \\
\hline $\mathrm{H}_{2} \mathrm{~N}-\mathrm{CH}_{2}-\mathrm{CH}_{2}-\mathrm{COOH}$ & - & 45.2 & - \\
\hline $\mathrm{H}_{2} \mathrm{~N}-\mathrm{CH}\left(\mathrm{CH}_{3}\right)-\mathrm{COOH}$ & - & 47.0 & - \\
\hline $\mathrm{H}_{2} \mathrm{~N}-\mathrm{CH}\left(\mathrm{CH}_{2}-\mathrm{CH}_{3}\right)-\mathrm{COOH}$ & - & 42.8 & - \\
\hline $\mathbf{C H}_{3}-\mathrm{CO}-\mathrm{NH}-\mathrm{CH}_{2}-\mathbf{C H}_{2}-\mathrm{COOH}$ & 18.0 & 16.3 & 2.1 \\
\hline $\mathbf{C H}_{3}-\mathrm{CO}-\mathrm{NH}-\mathrm{CH}_{2}-\mathbf{C H}_{2}-\mathbf{C H}_{2}-\mathrm{COOH}$ & 15.2 & 16.1 & 2.1 \\
\hline $\mathbf{C H}_{3}-\mathrm{CO}-\mathrm{NH}-\mathrm{CH}\left(\mathbf{C H}_{3}\right)-\mathrm{COOH}$ & 17.2 & 17.8 & 4.6 \\
\hline $\mathbf{C H}_{3}-\mathrm{CO}-\mathrm{NH}-\mathrm{CH}\left(\mathbf{C H}_{2}-\mathbf{C H}_{3}\right)-\mathrm{COOH}$ & 18.0 & 19.5 & 5.7 \\
\hline $\mathbf{C H}_{3}-\mathrm{CO}-\mathrm{NH}-\mathrm{CH}\left(\mathbf{C H}_{2}-\left(\mathbf{C H}_{3}\right)_{2}\right)-\mathrm{COOH}$ & - & 30.9 & - \\
\hline $\mathbf{C H}_{3}-\left(\mathbf{C H}_{2}\right)_{4}-\mathrm{CO}-\mathrm{NH}-\mathrm{CH}_{2}-\mathbf{C H}_{2}-\mathrm{COOH}$ & - & 27.2 & - \\
\hline $\mathbf{C H}_{3}-\left(\mathbf{C H}_{2}\right)_{4}-\mathrm{CO}-\mathrm{NH}-\mathrm{CH}\left(\mathbf{C H}_{3}\right)-\mathrm{COOH}$ & - & 27.0 & - \\
\hline $\mathbf{C H}_{3}-\left(\mathbf{C H}_{2}\right)_{8}-\mathrm{CO}-\mathrm{NH}-\mathrm{CH}_{2}-\mathbf{C H}_{2}-\mathrm{COOH}$ & - & 27.5 & - \\
\hline $\mathbf{C H}_{3}-\left(\mathbf{C H}_{2}\right)_{8}-\mathrm{CO}-\mathrm{NH}-\mathrm{CH}\left(\mathbf{C H}_{3}\right)-\mathrm{COOH}$ & - & 27.3 & - \\
\hline
\end{tabular}

The first observation is that the acylation decreases the inhibition activity at all $\mathrm{pH}$ values. The efficacy data show that a more hydrophobic carbon chain either in the amino acid of in the acyl moiety could not improve the anticorrosion effectiveness. The activities 
in the acidic as well as in alkaline environments are worth than in neutral one. These molecules are also not proper inhibitors in neutral environment but under extra acidic conditions the decylamide derivative of glycine is mentioned as good inhibitor [10].

\subsubsection{Derivatives of valine and norvaline}

Table 3. Anticorrosion activity of acyl derivatives of valine and norvaline ([I]: $100 \mathrm{ppm}$ ).

\begin{tabular}{|c|c|c|c|}
\hline \multirow{2}{*}{ Molecules under investigation } & \multicolumn{3}{|c|}{ Corrosion efficiency $\eta(\%)$} \\
\hline & $\mathrm{pH}=\mathbf{5 . 5}$ & $\mathbf{p H}=\mathbf{7 . 0}$ & $\mathrm{pH}=\mathbf{8 . 5}$ \\
\hline $\mathbf{H}_{2} \mathrm{~N}-\mathrm{CH}\left(\mathrm{CH}_{2}-\mathrm{CH}_{2}-\mathrm{CH}_{3}\right)-\mathrm{COOH}$ & 7.5 & 6.4 & 6.4 \\
\hline $\mathbf{C H}_{3}-\mathrm{CO}-\mathrm{HN}-\mathrm{CH}\left(\mathbf{C H}_{2}-\mathbf{C H}_{2}-\mathbf{C H}_{3}\right)-\mathrm{COOH}$ & - & 26.8 & 2.1 \\
\hline $\mathbf{C l}-\mathbf{C H}_{2}-\mathrm{CO}-\mathrm{HN}-\mathrm{CH}\left(\mathbf{C H}_{2}-\mathbf{C H}_{2}-\mathbf{C H}_{3}\right)-\mathrm{COOH}$ & 9.3 & 10.2 & 9.7 \\
\hline $\mathbf{C H}_{3}-\left(\mathbf{C H}_{2}\right)_{4}-\mathrm{CO}-\mathrm{HN}-\mathrm{CH}\left(\mathbf{C H}_{2}-\mathbf{C H}_{2}-\mathbf{C H}_{3}\right)-\mathrm{COOH}$ & 3.4 & 35.0 & 16.5 \\
\hline $\mathbf{C H}_{3}-\left(\mathbf{C H}_{2}\right)_{8}-\mathrm{CO}-\mathrm{HN}-\mathrm{CH}\left(\mathbf{C H}_{2}-\mathbf{C H}_{2}-\mathbf{C H}_{3}\right)-\mathrm{COOH}$ & 35.7 & 75.3 & 66.5 \\
\hline$\left(\mathbf{C H}_{3}\right)_{3} \mathbf{C}-\mathrm{CO}-\mathrm{HN}-\mathrm{CH}\left(\mathbf{C H}_{2}-\mathbf{C H}_{2}-\mathbf{C H}_{3}\right)-\mathrm{COOH}$ & 8.1 & 14.6 & 7.1 \\
\hline $\mathbf{C}_{6} \mathbf{H}_{5}-\mathrm{CO}-\mathrm{HN}-\mathrm{CH}\left(\mathbf{C H}_{2}-\mathbf{C H}_{2}-\mathbf{C H}_{3}\right)-\mathrm{COOH}$ & - & 15.0 & - \\
\hline$p-\mathbf{C H}_{3}-\mathbf{C}_{6} \mathbf{H}_{4}-\mathrm{CO}-\mathrm{HN}-\mathrm{CH}\left(\mathbf{C H}_{2}-\mathbf{C H}_{2}-\mathbf{C H}_{3}\right)-\mathrm{COOH}$ & 4.7 & 2.5 & 5.8 \\
\hline $\boldsymbol{p}-\mathrm{NO}_{2}-\mathbf{C}_{6} \mathbf{H}_{4}-\mathrm{CO}-\mathrm{HN}-\mathrm{CH}\left(\mathrm{CH}_{2}-\mathbf{C H}_{2}-\mathbf{C H}_{3}\right)-\mathrm{COOH}$ & -12.7 & 19.5 & 1.6 \\
\hline $\mathbf{C}_{6} \mathbf{H}_{5}-\mathbf{C H}_{2}-\mathrm{CO}-\mathrm{HN}-\mathrm{CH}\left(\mathbf{C H}_{2}-\mathbf{C H}_{2}-\mathbf{C H}_{3}\right)-\mathrm{COOH}$ & - & 20.1 & - \\
\hline $\mathbf{C}_{6} \mathbf{H}_{5}-\mathbf{C H}_{2}-\mathbf{C H}_{2}-\mathrm{CO}-\mathrm{HN}-\mathrm{CH}\left(\mathbf{C H}_{2}-\mathbf{C H}_{2}-\mathbf{C H}_{3}\right)-\mathrm{COOH}$ & - & 16.1 & - \\
\hline $\mathbf{C}_{6} \mathbf{H}_{5}-\mathbf{C H}=\mathbf{C H}-\mathrm{CO}-\mathrm{HN}-\mathrm{CH}\left(\mathbf{C H}_{2}-\mathbf{C H}_{2}-\mathbf{C H}_{3}\right)-\mathrm{COOH}$ & - & 29.7 & - \\
\hline $\mathbf{C}_{6} \mathbf{H}_{5}-\mathbf{O}-\mathrm{CO}-\mathrm{HN}-\mathrm{CH}\left(\mathbf{C H}_{2}-\mathbf{C H}_{2}-\mathbf{C H}_{3}\right)-\mathrm{COOH}$ & - & -9.7 & - \\
\hline $\mathrm{H}_{2} \mathrm{~N}-\mathrm{CH}\left(\mathrm{CH}\left(\mathrm{CH}_{3}\right)_{2}\right)-\mathrm{COOH}$ & 13.4 & 11.5 & 13.5 \\
\hline $\mathbf{C H}_{3}-\left(\mathbf{C H}_{2}\right)_{8}-\mathrm{CO}-\mathrm{HN}-\mathrm{CH}\left(\mathbf{C H}\left(\mathbf{C H}_{3}\right)_{2}\right)-\mathrm{COOH}$ & 3.4 & 33.2 & 11.3 \\
\hline
\end{tabular}

Interestingly the efficacy of the free amino acids is very low at all investigated $\mathrm{pH}$ values. Increase in the anticorrosion efficacy could be achieved only in case when both in the side chain of basic amino acid molecule and in the acyl moiety the hydrophobicity increases. Some researchers observed similar phenomenon $[11,12]$ in experiments in the presence of other metals. The reason could be explained by the inductive effect all along the carbon chains. In our case the increase in the anticorrosion efficacy (at $\mathrm{pH} 7: 75.3 \%$ ) is due to the common positive effect of the carbon chain of medium length. Under the given experimental conditions the activity of acylated valine and norvaline decreases when the solution is either acidic or alkaline. When an aromatic ring in the alkyl moiety is nearer to the acid amid bond, it has a positive effect on the activity. The substituents in the phenyl ring either with electron sending or withdrawing activity do not influence the anticorrosion effect. 
3.2.3. The pH-dependent anticorrosion activity of phenylalanine derivatives

Table 4. Activity of acyl derivatives of phenylalanine ([I]: $100 \mathrm{ppm}$ ).

\begin{tabular}{|c|c|c|c|}
\hline \multirow{2}{*}{ Molecules under investigation } & \multicolumn{3}{|c|}{ Corrosion efficiency $\eta(\%)$} \\
\hline & $\mathrm{pH}=5.5$ & $\mathbf{p H}=\mathbf{7 . 0}$ & $\mathrm{pH}=8.5$ \\
\hline $\mathrm{H}_{2} \mathrm{~N}-\mathrm{CH}\left(\mathrm{CH}_{2}-\mathrm{C}_{6} \mathbf{H}_{5}\right)-\mathrm{COOH}$ & - & 15.3 & - \\
\hline $\mathbf{C H}_{3}-\mathbf{C O}-\mathrm{NH}-\mathrm{CH}\left(\left(\mathbf{C H}_{2}-\mathbf{C}_{6} \mathbf{H}_{5}\right)\right)-\mathrm{COOH}$ & 18.9 & 18.3 & 11.1 \\
\hline $\mathbf{C H}_{3}-\left(\mathbf{C H}_{2}\right)_{4}-\mathbf{C O}-\mathrm{HN}-\mathrm{CH}\left(\mathbf{C H}_{2}-\mathbf{C}_{6} \mathbf{H}_{5}\right)-\mathrm{COOH}$ & 46.9 & 70.0 & 46.9 \\
\hline $\mathbf{C H}_{3}-\left(\mathbf{C H}_{2}\right)_{8}-\mathbf{C O}-\mathrm{HN}-\mathrm{CH}\left(\mathbf{C H}_{2}-\mathbf{C}_{6} \mathbf{H}_{5}\right)-\mathrm{COOH}$ & 49.4 & 59.6 & 58.7 \\
\hline $\mathbf{C}_{6} \mathbf{H}_{5}-\mathbf{C O}-\mathrm{HN}-\mathrm{CH}\left(\mathbf{C H}_{2}-\mathbf{C}_{6} \mathbf{H}_{5}\right)-\mathrm{COOH}$ & - & 23.4 & - \\
\hline
\end{tabular}

The observations discussed in case of amino acids with hydrophobic side chains are valid for the phenylalanine derivatives, too: increase in the hydrophobic character both of the amino acid and the acyl part increases the anticorrosion activity. Important difference is that the change in the $\mathrm{pH}$ of the environment has less influence on the anticorrosion effectiveness.

\subsection{The influence of ionizable group in the amino acid side chains}

\subsubsection{The pH-dependent anticorrosion behavior of acyl aspartic acids}

The sensitivity of corrosion rate to the $\mathrm{pH}$ values decreases when the hydrophobicity of the acyl part increases. The chlorine substituent in the aryl group negatively influences the anticorrosion activity which shows that the electron-withdrawing activity influences the electron distribution on the $\mathrm{CO}-\mathrm{NH}$ group. This indicates that in the case of these molecules the inhibition is not only influenced by the carboxylic groups but through the acid amid groups, too. When the polarity of the $\mathrm{CO}-\mathrm{NH}$ group changes e.g. through a chlorine atom, the anticorrosion effect decreases significantly.

Table 5. The pH-dependent anticorrosion activity of aspartic acid derivatives.

\begin{tabular}{rccc}
\hline \multirow{2}{*}{ Molecules under investigation } & \multicolumn{3}{c}{ Corrosion efficiency $\boldsymbol{\eta}(\%)$} \\
\cline { 2 - 4 } & $\mathbf{p H}=\mathbf{5 . 5}$ & $\mathbf{p H}=\mathbf{7 . 0}$ & $\mathbf{p H}=\mathbf{8 . 5}$ \\
\hline $\mathrm{H}_{2} \mathrm{~N}-\mathrm{CH}\left(\mathrm{CH}_{2}-\mathrm{COOH}\right)-\mathrm{COOH}$ & 46.1 & 66.2 & -16.8 \\
$\mathbf{C H}_{3}-\mathrm{CO}-\mathrm{HN}-\mathrm{CH}\left(\mathbf{C H}_{2}-\mathrm{COOH}\right)-\mathrm{COOH}$ & - & 12.3 & - \\
$\mathbf{C H}_{3}-\left(\mathbf{C H}_{2}\right)_{4}-\mathrm{CO}-\mathrm{HN}-\mathrm{CH}\left(\mathbf{C H}_{2}-\mathrm{COOH}\right)-\mathrm{COOH}$ & 30.5 & 89.9 & 31.2 \\
$\mathbf{C H}_{3}-\left(\mathbf{C H}_{2}\right)_{8}-\mathrm{CO}-\mathrm{HN}-\mathrm{CH}\left(\mathbf{C H}_{2}-\mathrm{COOH}\right)-\mathrm{COOH}$ & 68.7 & 75.1 & 77.7 \\
$\mathbf{C}_{\mathbf{1 5}} \mathbf{H}_{31}-\mathrm{CO}-\mathrm{HN}-\mathrm{CH}\left(\mathbf{C H}_{2}-\mathrm{COOH}\right)-\mathrm{COOH}$ & - & 75.1 & - \\
$\mathbf{C}_{\mathbf{6}} \mathbf{H}_{5}-\mathrm{CO}-\mathrm{HN}-\mathrm{CH}\left(\mathbf{C H}_{2}-\mathbf{C O O H}\right)-\mathrm{COOH}$ & - & 36.1 & -
\end{tabular}




\begin{tabular}{cccc}
\hline \multirow{2}{*}{ Molecules under investigation } & \multicolumn{2}{c}{ Corrosion efficiency $\boldsymbol{\eta}(\%)$} \\
\cline { 2 - 3 } $\boldsymbol{o}-\mathbf{C l}-\mathbf{C}_{\mathbf{6}} \mathbf{H}_{4}-\mathrm{CO}-\mathrm{HN}-\mathrm{CH}\left(\mathbf{C H}_{2}-\mathrm{COOH}\right)-\mathrm{COOH}$ & $\mathbf{p H}=\mathbf{5 . 5}$ & $\mathbf{p H}=\mathbf{7 . 0}$ & $\mathbf{p H}=\mathbf{8 . 5}$ \\
\hline $\mathbf{C}_{\mathbf{6}} \mathbf{H}_{\mathbf{5}}-\mathbf{C H}=\mathbf{C H}-\mathrm{CO}-\mathrm{HN}-\mathrm{CH}\left(\mathbf{C H}_{2}-\mathbf{C O O H}\right)-\mathrm{COOH}$ & - & -2.6 & - \\
\hline
\end{tabular}

\subsubsection{The pH-dependent anticorrosion behavior of acyl glutamic acids}

Table 6. The pH-dependent anticorrosion activity of glutamic acid derivatives ([I]: $100 \mathrm{ppm}$ ).

\begin{tabular}{|c|c|c|c|}
\hline \multirow{2}{*}{ Molecules under investigation } & \multicolumn{3}{|c|}{ Corrosion efficiency $\eta(\%)$} \\
\hline & $\mathrm{pH}=\mathbf{5 . 5}$ & $\mathbf{p H}=\mathbf{7 . 0}$ & $\mathrm{pH}=8.5$ \\
\hline $\mathrm{H}_{2} \mathrm{~N}-\mathrm{CH}\left(\mathrm{CH}_{2}-\mathbf{C H}_{2}-\mathbf{C O O H}\right)-\mathrm{COOH}$ & 34.5 & 21.1 & -43.0 \\
\hline $\mathbf{C H}_{3}-\mathrm{CO}-\mathrm{HN}-\mathrm{CH}\left(\mathbf{C H}_{2}-\mathbf{C H}_{2}-\mathbf{C O O H}\right)-\mathrm{COOH}$ & - & 16.3 & - \\
\hline $\mathbf{C l C H}_{2}-\mathrm{CO}-\mathrm{HN}-\mathrm{CH}\left(\mathbf{C H}_{2}-\mathbf{C H}_{2}-\mathbf{C O O H}\right)-\mathrm{COOH}$ & - & 10.2 & - \\
\hline $\mathbf{C H}_{3}-\left(\mathbf{C H}_{2}\right)_{4}-\mathrm{CO}-\mathrm{HN}-\mathrm{CH}\left(\mathbf{C H}_{2}-\mathbf{C H}_{2}-\mathbf{C O O H}\right)-\mathrm{COOH}$ & 30.5 & 65 & 17.1 \\
\hline $\mathbf{C H}_{3}-\left(\mathbf{C H}_{2}\right)_{8}-\mathrm{CO}-\mathrm{HN}-\mathrm{CH}\left(\mathbf{C H}_{2}-\mathbf{C H}_{2}-\mathbf{C O O H}\right)-\mathrm{COOH}$ & 92.1 & 85.1 & 64.5 \\
\hline $\mathbf{C}_{15} \mathbf{H}_{31}-\mathrm{CO}-\mathrm{HN}-\mathrm{CH}\left(\mathbf{C H}_{2}-\mathbf{C H}_{2}-\mathbf{C O O H}\right)-\mathrm{COOH}$ & - & 72.2 & - \\
\hline $\mathbf{C}_{6} \mathbf{H}_{5}-\mathrm{CO}-\mathrm{HN}-\mathrm{CH}\left(\mathbf{C H}_{2}-\mathbf{C H}_{2}-\mathbf{C O O H}\right)-\mathrm{COOH}$ & - & 34.0 & - \\
\hline $\mathbf{C}_{6} \mathbf{H}_{5}-\mathbf{C H}=\mathbf{C H}-\mathrm{CO}-\mathrm{HN}-\mathrm{CH}\left(\mathbf{C H}_{2}-\mathbf{C H}_{2}-\mathbf{C O O H}\right)-\mathrm{COOH}$ & - & 82.6 & - \\
\hline $\boldsymbol{p}-\mathbf{C H}_{3}-\mathbf{C}_{6} \mathbf{H}_{4}-\mathrm{CO}-\mathrm{HN}-\mathrm{CH}\left(\mathbf{C H}_{2}-\mathbf{C H}_{2}-\mathbf{C O O H}\right)-\mathrm{COOH}$ & - & 2.5 & - \\
\hline $\boldsymbol{p}-\mathrm{NO}_{2}-\mathbf{C}_{6} \mathbf{H}_{4}-\mathrm{CO}-\mathrm{HN}-\mathrm{CH}\left(\mathbf{C H}_{2}-\mathbf{C H}_{2}-\mathbf{C O O H}\right)-\mathrm{COOH}$ & - & 19.5 & - \\
\hline \multicolumn{4}{|l|}{ The capryl derivative of lysine } \\
\hline$-\left(\mathbf{C H}_{2}\right)_{8}-\mathrm{CO}-\mathrm{HN}-\mathrm{CH}\left(\mathrm{CH}_{2} \mathbf{C H}_{2} \mathbf{C H}_{2}-\mathrm{CH}_{2}-\mathrm{NH}_{2}\right)-\mathrm{COOH}$ & - & 32.1 & - \\
\hline
\end{tabular}

The glutamic acid - similarly to the aspartic acid - when an additional carboxylic group is in the side chain, acylated with a carboxylic acid of longer alkyl chain, show good inhibitory activity. It should keep in mind that a longer alkyl group decreases the water solubility. When the inhibitor is already adsorbed onto the metal surface through the functional group, an insulating layer is formed at the metal-surface interface in an aqueous environment.

3.3.3 How does the $\mathrm{pH}$ of the environment influence the anticorrosion activity of acyl amino acids?

Data on anticorrosion efficacy summarized in Tables 1-6 show that in this group of molecules the change in the $\mathrm{pH}$ both in acidic and alkaline range decreases the anticorrosion effectiveness, irrespectively of the substituent both in the acyl part and in the side chain of the amino acids. This is interesting because the basic amino acids can control 
the corrosion under acidic conditions. It shows that the changed electron distribution in one of the functional groups of amino acids (i.e. on the nitrogen in the $\mathrm{CO}-\mathrm{NH}$ group) affects the anticorrosion activity. This is valid for all amino acids under investigation. If there was not any side chain (glycine) or there were hydrophobic alkyl substituents (alanine, valine, norvaline, phenylalanine), as well as in case of presence of additional carboxylic group (aspartic acid, glutamic acid) the shift of $\mathrm{pH}$ from the neutral value into acidic or alkaline range decreases the anticorrosion activity less or better.

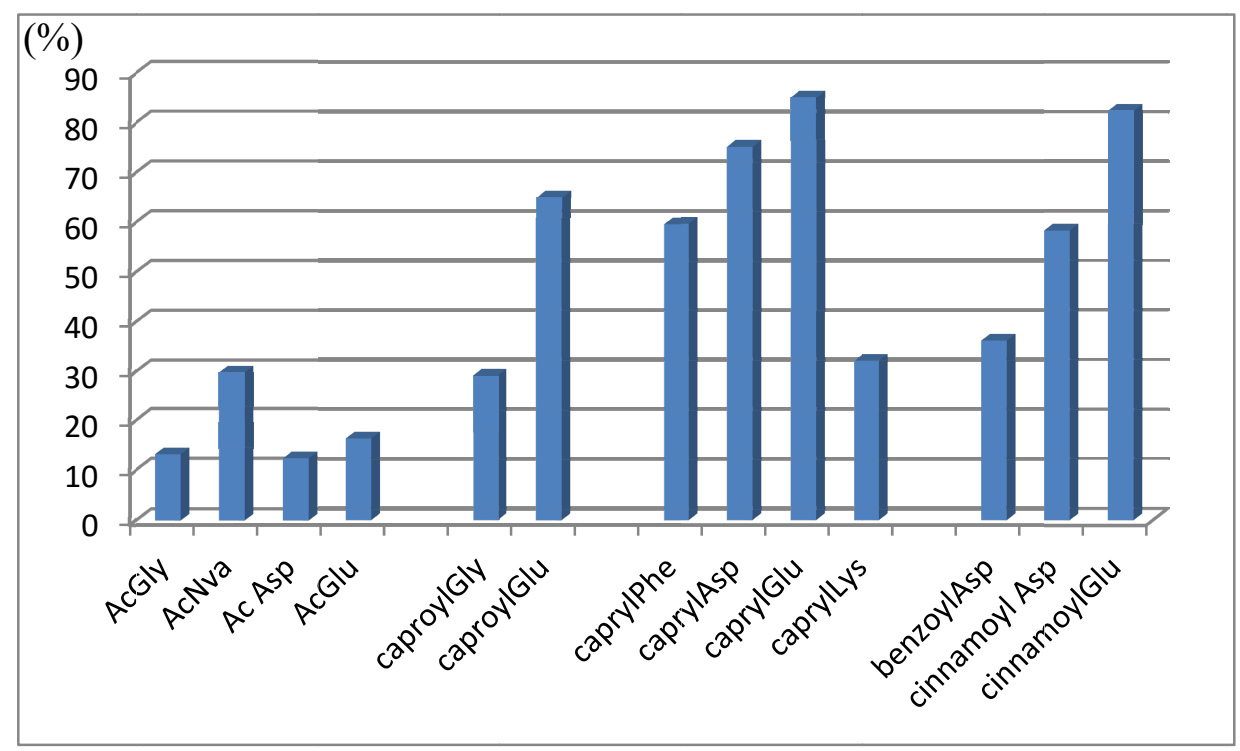

Figure 1. Anticorrosion activity of some acyl amino acids; acyl moieties are the follows: acetyl (Ac); caproyl, capryl, benzoyl, cinnamoyl; amino acids are the follows: Gly:glycine, Nva:norvaline, Asp: aspartic acid, Glu: glutamic acid, Phe: phenylalanine, Lys: lysine. $([\mathrm{I}]=100 \mathrm{ppm})$.

Mainly in case of weak inhibitors the change from the neutral to the alkaline $\mathrm{pH}$ range causes altered effectiveness. At the aspartic and glutamic acid derivatives there is an additional carboxylic group. The decrease in the activity at $\mathrm{pH}$ values lower than the neutral one shows the negative effect of the protonated carboxylic group in the inhibition. When the $\mathrm{pH}$ value is higher than the neutral one, the negatively charged $\mathrm{COO}^{-}$group decreases the possibility of adsorption.

Some of results listed in the previous tables are depicted in Figure 1 where the corrosion inhibiting activities are demonstrated. This adds up to the influence of the alkyl chain both in the acyl moiety and in the side chain of the amino acids, on one hand, and, on the other hand, the importance of an additional carboxylic group in the amino acid.

\subsection{Surface visualization by atomic force microscopy}

The change in the surface roughness caused by the model solution with and without inhibitors is demonstrated by $3 \mathrm{D}$ and section images got by atomic force microscope 
(Figure 2). The polished carbon steel surface was visualized on air, without any treatment (to show the basic state of the metal surface), and after immersion into the model solution.

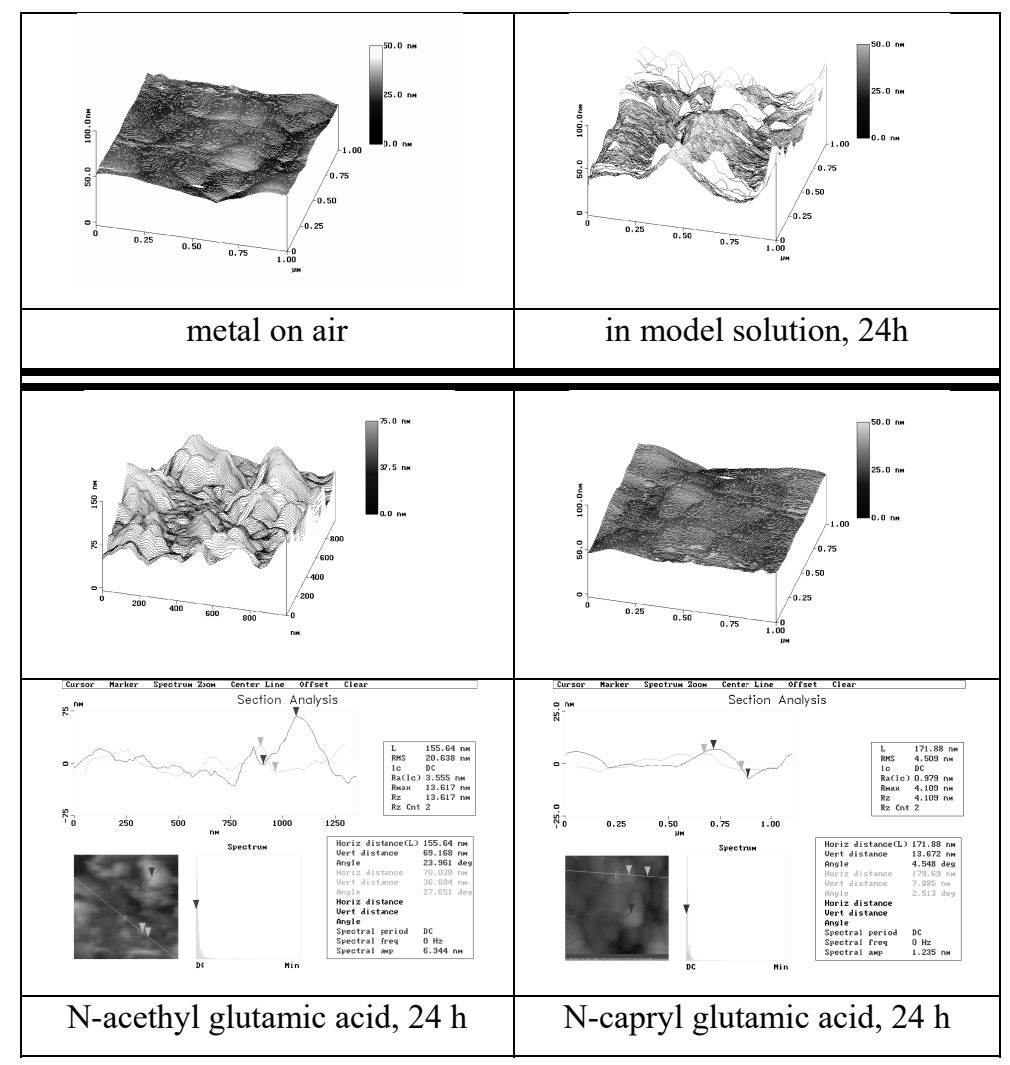

Figure 2. 3D and section AFM images of carbon steel surfaces taken after 24 hours in model solution, with and without inhibitors.

One of the inhibitors was a less effective (acetyl glutamic acid), the other (capryl glutamic acid) showed very good anticorrosion activity in gravimetric test. The polished metal sample is very smooth, but the model solution increased the surface roughness significantly. When the less effective inhibitor was present in the model solution, the surface turned to be very rough which was confirmed by the section analysis. On the other hand, the molecule with longer alkyl moiety in the acyl part did not allow the surface roughening; the very smooth surface demonstrates the inhibited metal dissolution.

\section{Conclusion}

The acyl amino acids show good inhibitory activity only in that cases when a longer (more hydrophobic) alkyl or aralkyl groups were either in the amino acid or in the acyl part. An additional carboxylic group in the amino acid increases the anticorrosion activity. The best is when both groups with positive effect are present in the inhibitor molecule as their activity will sum up. The anticorrosion activity measured by gravimetric method was supported by the surface visualization via atomic force microscopy. The changes of the metal surface morphology caused by positive or negative effect of acyl amino acids applied 
as inhibitors were demonstrated in $3 \mathrm{D}$ and section figures. The roughening caused by the aggressive solution was decreased dramatically with the presence of the good anticorrosion additive and, in the other sat of experiments, was rough when a less effective molecule was present.

\section{References}

1. M. Dehdab, M. Shahraki and S.M. Habibi-Khorassani, Amino Acids, 2016, 48, 291.

2. M. Yadav, T.K. Sarkar and T. Purkait, J. Mol. Liq., 2015, 212, 731.

3. M. Yadav, S. Kumar and L. Gope, J. Adhes. Sci. Technol., 2014, 28, 1072.

4. M.M. Kabanda, I.B. Obot, E.E. Ebenso, Int. J. Electrochem. Sci., 2013, 8, 10839.

5. A. Aouniti, K.F. Khaled and B. Hammouti, Int. J. Electrochem. Sci., 2013, 8, 5925.

6. M. Alagbe, L.E. Umoru, A.A. Afonja and O.E. Olorunniwo, Anti-Corros. Methods Mater., 2009, 56, 43.

7. J. Telegdi and J. Beczner, Int. J. Corros. Scale Inhib., 2014, 3, no. 3, 167. doi: 10.17675/2305-6894-2014-3-3-167-176

8. J. Telegdi, Int. J. Corros. Scale Inhib., 2016, 5, no. 2, 183. doi: 10.17675/2305-68942016-5-2-7

9. J.P. Greenstein and M. Winitz, Chemistry of Amino Acids, John Wiley \& Sons Inc., N.Y., London, 1961.

10. O. Olivares, N.V. Likhanova, B. Gómez, J. Navarrete, M.E. Llanos-Serrano, E. Arce and J.M. Hallen, Appl. Surf. Sci., 2006, 252, no. 8, 2894.

11. M.S. Morsi, Werst. Korros., 1993, 44, 304.

12. G. Trabanelli, Corrosion inhibitors, in "Corrosion Mechanisms", ed. F. Mansfeld, Marcel Dekker, New York, 1987. 